\title{
Importance of Functionality in Realizing Sustainability of Low Cost Apartments in Surabaya, Indonesia
}

\author{
Rika Kisnarini, Emilia van Egmond, Masi Mohammadi, Eindhoven University of Technology
}

\begin{abstract}
This paper researches daily household activities and use of space at low cost apartments in Surabaya, Indonesia. In-depth interviews on where \& how much space required for activities were done. Functionality is assessed by standards and classified as highly, functional, less, and non-functional. Findings: 13 of 14 apartments have open floor plans with no fixed partitioning; $70 \%$ families tend to separate private from the more public space; families entertain, eat, iron, play, work and relax while watching $\mathrm{TV}$ in the more public space of multi-functional zone in the unit. Units are concluded less sufficient especially for multi-functional and toilet spaces. It is recommended that unit area of $18 \mathrm{~m}^{2}$ be discontinued. To be functional, developed unit should be at least $32 \mathrm{~m}^{2}$.
\end{abstract}

KEYWORDS: functionality, low cost apartments, users' activities, Surabaya, sustainability.

Presently, housing studies focus on sustainability worldwide. To be sustainable, a house should be more than a physical structure to people, it should be a home. Yet, the way home is defined varies considerably throughout literature and between individuals [4]. Home is defined as a social environment that depends on time or the impression of time and is represented by a personalized physical environment, such as a house that nurtures the attachment of meaning [9]. In this sense, a house is a physical structure that fulfills lower level needs such as protection from weather and intrusion, but the home will also fulfill higher-level needs, i.e. fulfilling one's ideals and values or creation of positive memories [1]

Recent research underpins that a better match between buildings and users' real needs will determine functionality and will influence the users' satisfaction. The inhabitants thus might be longer satisfied with the building, which leads to a higher level of durability of the building. There should be a capability amongst the stakeholders in the construction industry to meet the inhabitants' requirements. This capability refers to the ability to understand and translate the language in which the requirements are expressed by the users into that of the suppliers in the construction industry. In conclusion, to be functional and sustainable, a house should not act only as a dwelling but more as home. The designs and building systems should meet the users' requirements.
A lack of functionality is caused by insufficiency of dwelling space. Despite the wealth of studies on housing, also in tropical developing countries, literature study findings necessitate to echo. Priemus [3] stated that "there were too many theories and a lack of empirical evidence, an uneasy perspective for housing research". Social housing in the world showed a large uniformity in spatial arrangement of houses. They cannot easily be adapted to the requirements of individual households. This research particularly focuses on the functionality of low cost apartment space design. The main aim is to gain knowledge and understanding of particular users' demands for functionality of the space design. Functionality in this research means whether the activities of users held within the units can take place in a proper manner. More specifically, this research investigates whether the design of the apartment provides sufficient space for users to carry out their daily household activities.

\section{Methodology}

Voordt et al [16] states that functionality of a building refers to the extent, to which domestic activities are supported by the amount and form of space, and spatial relationship between rooms. Also, World Building Design Guide (WBDG) [17] and West Beverly N. [14] reveal that functionality of buildings refers to adequacy of space design and room dimensions to allow occupants to carry out their daily activities. The demands of users for space can be determined by investigating the users' activities (Manning [15] and Voordt et al [16]). Accordingly, the functionality of the space design can be assessed by checking whether the space size for conducting a particular activity meets the minimum standards. Most scholars in previous studies on apartment space design (e.g. by Demirkan and Kutlusoy [8]; Saarikangas [11]; Breitbart [7] and Minami [10]) have acknowledged the importance of users' characteristics since these have impact on their activities and thus on their particular space demands. These viewpoints has led to the application of activity based approach in this research, thereby taking into account the users' characteristics that determine the activities and resulting space demand.

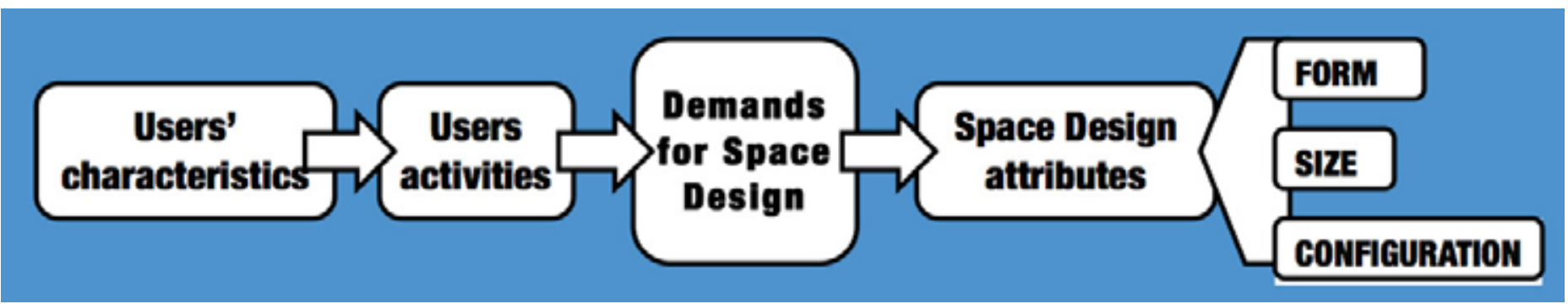

Fig. 1. Demands for space designs are approached through users' activities influenced by users' characteristics. 
Based on the theoretical framework (Figure 1), research instruments have been developed by finding a list of household activities carried out by the users of low cost apartments in Surabaya, Indonesia, in the daily life. This has been done by investigating literature, as well as consulting and discussing it with experts in the fields. This list has been used to prepare questionnaires for data collection. The data required in this research is obtained by questionnaires and the in-depth interviews. 300 respondents of 14 building population, 21 households in each apartment block, are taken as samples. The data collected in the field survey includes the information on where and how much space is required for doing each activity; basic characteristics of user population; and space design of the 14 apartment buildings by interviewing and obtaining the drawings from local authorities. All data of plans are (re-)drawn and processed by using CAD. Processing of the remaining data is carried out by using Excel.

\section{RESULTS}

The Standard Requirements. The functionality in this paper is assessed by comparing the space area used in the existing plan to the standard requirement in literature. In selecting the available literature, the dominant household member resulted in this research guides. Therefore 4 people as the nominating household member is being the key. This dominant household member that assumed to be 2 parents and 2 children is used in choosing which house type to be taken as the comparison. The most local requirements are prioritized. Therefore, the standard of Indonesia, released by Pusat Penelitian dan Pengembangan PU (Development and Research Center, Public Works) 1984 in Table 1, is applied. All spaces referred and listed below are those applied to 4 people, the dominant household member.

TABLE 1

NATIONAL STANDARD OF HOUSE SPACES FOR 4 PEOPLE CONSISTS OF 2 PARENTS AND 2 children. Source: Board of Research and Development, Public Works INDONESIA.

\begin{tabular}{|l|l|c|}
\hline & Space & Area $\left(\mathbf{m}^{2}\right)$ \\
\hline 1 & House in Indonesia for 4 people & 48 \\
\hline 2 & Sitting + Dining (Living room) & 13.6 \\
\hline \multirow{2}{*}{3} & Sleeping (master bedroom) & 9.3 \\
\cline { 2 - 3 } & Sleeping (one double bedroom) & 9 \\
\hline 4 & Kitchen & 4 \\
\hline 5 & Bathroom (toilet) \& WC & 2.52 \\
\hline 6 & Washing & 3 \\
\hline 7 & Ironing & 3 \\
\hline
\end{tabular}

The standard space area for the whole unit is that for grounded individual house, instead of apartment unit. The standard house area covers its own fixed living-room, bedroom, dining-room, kitchen, bathroom, and storage, for 2 parents and 2 children. While the units assessed are mostly open plan apartments, in which activities are mixed with each other in unit zones, particularly in multi-functional zone. Thus, this Indonesian standard is less comparable for the whole unit. That is why a different standard for apartment is needed. The international apartment guidelines by ACT [13] describe that minimum standard for studio apartment is $40 \mathrm{sqm}$.
The Apartment Floor Plans. In order to enable analysis and ease comparability to available standard requirements, it is necessary to group the collected unit floor plans into smaller groups. Amongst 14 apartment buildings, there is only one with fixed partitioning in its floor plan. Mostly, the existing units of low cost apartments in Surabaya, 13 out of 14, are designed in open plan. It means that in selecting the standard reference, they are considered to be studio. More specifically, the units are classified into four patterns: (1) Fixed plan with one fixed bedroom and individual toilet, pantry, and balcony; (2) Open plan with collectively provided toilet and pantry; (3) Units with private toilet and pantry, some of which have their toilet and pantry located outside or at the balcony, and (4) Units with toilet and pantry inside as they have no balcony.

To facilitate the evaluation of functionality, the floor-plans were subdivided into zones. Each particular zone facilitates several household activities, which by this research were found to be dominant activities, taking place in the zone. This zoning is necessary since standard requirements for different spaces in the floor-plan are indicated by their aggregated functional space in literature instead of space for each activity. For instance, it is easier to find references for space requirements such as for livingroom, dining-room, and bedroom then for drying, eating, praying etc. Therefore, zoning of classified unit plans that divide units into multi-function, kitchen, toilet, and balcony zones, is derived.

TABLE 2

AVERAGE AREA OF EXISTING (UNIT) ZONES / SPACES.

\begin{tabular}{|c|l|c|c|c|}
\hline \multirow{2}{*}{$\begin{array}{c}\text { Units } \\
\text { having } \\
\text { zones }\end{array}$} & \multicolumn{1}{|c|}{ Zone } & \multicolumn{3}{|c|}{ Zone Area } \\
\cline { 3 - 5 } & & Average & Max & Min \\
\hline 300 & Whole unit & $23.1 \mathrm{~m} 2$ & 32 & 19.2 \\
\hline 300 & Multi-function & $17.7 \mathrm{~m} 2$ & 23.5 & 15.2 \\
\hline 195 & Balcony & $2.6 \mathrm{~m} 2$ & 4.5 & 1.2 \\
\hline 126 & Kitchen & $2.6 \mathrm{~m} 2$ & 4 & 1.5 \\
\hline 195 & Toilet & $2.6 \mathrm{~m} 2$ & 3.5 & 2 \\
\hline
\end{tabular}

The Floor Plan Spaces. As presented in the previous paragraph, not all units have balconies. Identically, not all units have kitchens and toilets, therefore in averaging the space area, the count of column member (unit having zones) is important. Moreover, area data of maximum and minimum are essential too especially for the assessment, in which, when average area is less functional to meet the standard, the maximum area may meet it. The average, maximum, and minimum space areas of those zones are listed in Table 2.

The average space area of each zone in Table 2 should manage to include all the use of space of its activity loads, each of which is averaged by calculating the plot area pointed by users indicating where and how much space is used. The data of average use of space in Table 3 below is applied to the assessing process, as the existing zone, to be compared to the standardized space, should be fulfilled with this use of space. That is why averaging the area of space use of each activity is obliged.

Daily Household Activities. One of the most important data collected in this research is related to the place, where each activity is carried out by the user. Result of excel process that indicates 
TABLE 3

RESULTS OF AVERAGE USE OF SPACE OF EACH ACTIVITY.

\begin{tabular}{|c|l|c|}
\hline & Activity & Average area \\
\hline A & Washing & 1.47 \\
\hline B & Drying & 1.65 \\
\hline C & Ironing & 1.64 \\
\hline D & Storing-1 & 0.75 \\
\hline F & Cooking & 2.22 \\
\hline G & Eating & 2.92 \\
\hline H & Dishwashing & 1.57 \\
\hline I & Storing-2 & 1.34 \\
\hline J & Bathing & 2.4 \\
\hline K & Sleeping & 4.57 \\
\hline L & Praying & 1.95 \\
\hline M & Studying & 4.1 \\
\hline N & Child-caring & 3.2 \\
\hline O & Storing-3 & 1.38 \\
\hline P & TV-watching & 3.85 \\
\hline Q & Relaxing & 3 \\
\hline R & Playing & 3.91 \\
\hline S & Entertaining & 3.47 \\
\hline T & Storing-4 & 1.07 \\
\hline
\end{tabular}

the dominant activities taken place in each zone, considered to be activity loads in Table 4 below, shows that multi-functional zone accommodates the most activities, by having 12 activities, in which kitchen only facilitates 3 , toilet 3 , and balcony 5 activities.

TABLE 4

ACTIVITY LOADS OF EACH ZONE.

\begin{tabular}{|c|c|c|c|}
\hline $\begin{array}{c}\text { Multi-Functional } \\
\text { zone }\end{array}$ & $\begin{array}{c}\text { Kitchen } \\
\text { zone }\end{array}$ & Toilet zone & $\begin{array}{l}\text { Balcony } \\
\text { zone }\end{array}$ \\
\hline $\begin{array}{ll}\text { 1. } & \text { Ironing } \\
\text { 2. } & \text { Eating } \\
\text { 3. } & \text { Storing-2 } \\
\text { 4. } & \text { Sleeping } \\
\text { 5. } & \text { Praying } \\
\text { 6. } & \text { Studying } \\
\text { 7. } & \text { Child-caring } \\
\text { 8. } & \text { Storing-3 } \\
\text { 9. } & \text { TV-watching } \\
\text { 10. } & \text { Relaxing } \\
\text { 11. } & \text { Entertaining } \\
\text { 12. } & \text { Storing-4 }\end{array}$ & $\begin{array}{l}\text { 1. Cooking } \\
\text { 2. Dish- } \\
\text { washing } \\
\text { 3. Storing-2 }\end{array}$ & $\begin{array}{ll}\text { 1. } & \text { Washing } \\
\text { 2. } & \text { Storing-1 } \\
\text { 3. } & \text { Bathing }\end{array}$ & $\begin{array}{l}\text { 1. Drying } \\
\text { 2. Storing-1 } \\
\text { 3. Cooking } \\
\text { 4. Dish- } \\
\text { washing } \\
\text { 5. Storing-2 }\end{array}$ \\
\hline
\end{tabular}

From Table 4, kitchen and toilet are zones that directly have comparable standardized spaces (Table 1). On the contrary, multi-functional zone needs further steps to be comparable to the available standard spaces. One of findings in this research indicates the tendency that most respondents i.e. $70 \%$ families separate their private spaces from the more public spaces, in which, $51 \%$ use cupboard, $19 \%$ - partitions, $18 \%$ - curtains, and the rest $12 \%$ use others (walls) as the separator. This finding suggests subdivision of multi-functional zone that divides it into the more public and more private sub-zones.

600

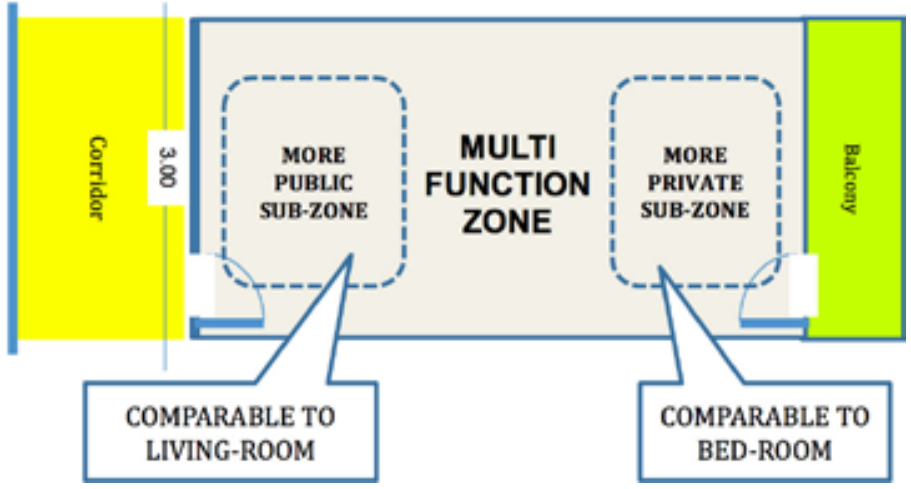

Fig. 2. Hypothetical division of multi-functional zone into more public and more private sub-zones.

The hypothetical division has to support the activity loads of multi-functional zone, as listed in Table 4. By further data processing, dominant activities, taking place in each sub-zone, then are indicated. Although they are subdivided, these sub-zones

TABLE 5

ACTIVITY LOADS OF MULTI-FUNCTIONAL SUB-ZONES COMPARABLE TO THE LIVING-ROOM AND BEDROOM.

The more public sub-zone

$\begin{array}{ll}\text { 1. } & \text { Entertaining } \\ \text { 2. } & \text { Eating } \\ \text { 3. } & \text { TV-watching } \\ \text { 4. } & \text { Ironing } \\ \text { 5. } & \text { Playing } \\ \text { 6. } & \text { Storing-4 }\end{array}$

6. Storing-4
The more private sub-zone

\begin{tabular}{|c|cc|c|}
$\begin{array}{c}\text { Comparable } \\
\text { to the }\end{array}$ & 1. & Sleeping & \\
living-room & Relaxing & Praying & Comparable \\
(sitting & 4. & Studying & to bedroom \\
and dining & 5. & Storing-2 & \\
room) & 6. & Storing-3 & \\
\hline
\end{tabular}

are interrelated closely. The activity loads of each sub-zone is determined as listed in the following Table 5 .

Furniture and Appliances. In the arrangement of existing unit plans, a set of furniture or equipment and appliances are involved in the space design. In the assessment phase, furniture applied to the existing unit is at least comparable to the one involved in the standard. Dominant furniture and appliances are those used in $>3$ activities, indicated as the most basic furniture \& means that should be at least available in low cost apartment units.

TABLE 6

THE USE OF DOMINANT FURNITURE IN ACTIVITIES.

\begin{tabular}{|c|l|}
\hline Total activities & \multicolumn{1}{c|}{ Furniture } \\
\hline 3 & Table \\
\hline 5 & Bucket \\
\hline 4 & Rack \\
\hline 4 & Cupboard \\
\hline 7 & Bed \\
\hline 13 & Mattress \\
\hline 7 & Fan \\
\hline 4 & TV set \\
\hline 6 & Water \\
\hline 5 & Sewer \\
\hline 11 & Electricity \\
\hline
\end{tabular}



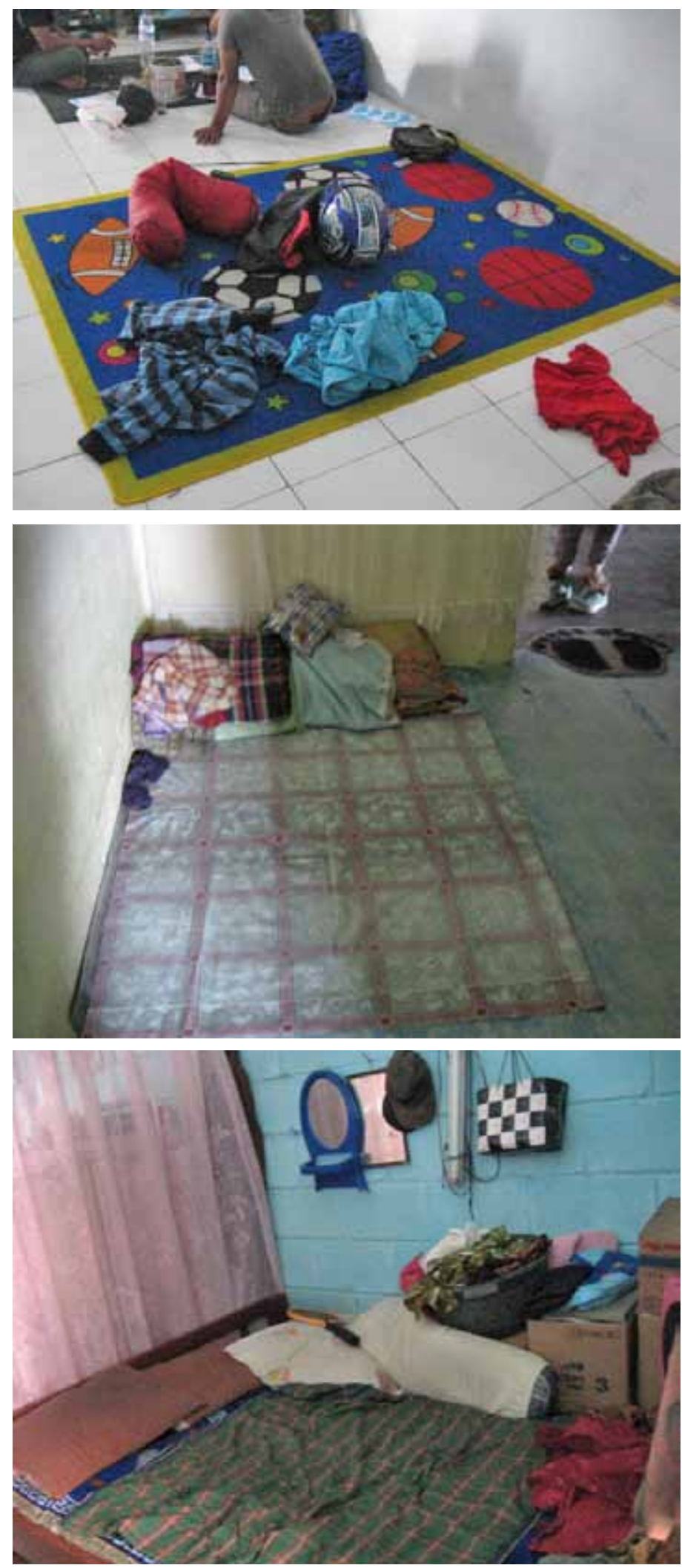

Fig. 3-5. Mattress as the multi-use furniture in low cost apartments.

\section{ANALYSIS}

Functionality in this research is assessed in \% by considering its capability in approaching the standard. The whole unit and zones of low cost apartments are therefore judged as highly functional when they meet the standard or more than $100 \%$ of standard requirement. They are scored functional when they reach $80 \%$ to $100 \%$. Less functional is given when achievement is $60 \%-80 \%$, and they are considered not functional when only manage to meet $<60 \%$ standard requirement. Functionality in this research is assessed by comparing either the average existing space (Table 2) or the zone area (Table 4 and 5) that is derived from total average use of space of activities included as loads (Table 3), to that space requirements are referred by standards (Table 1).

Functionality Assessment of the Whole Unit. The whole unit space is judged as not functional when assessed by using the national standard, as it is the standard for the individual housing. Even, when using the ACT apartment standard, the average existing unit area is still far below $40 \mathrm{sqm}$, the standard for studio apartment. When max area of 32 sqm is applied, the judgment moved closer to the standard, by reaching $80 \%$ of meeting capability.

Functionality Assessment of Kitchen. The activities in the existing kitchen are cooking, dishwashing, and storing-2 (Table 4) that are all exactly the same as those in the standardized kitchen. Thus, no deviation at all in this assessment, they are definitely comparable. The result of comparison of average existing kitchen is just functional. However, when the compared space is the kitchen zone, the functionality increased to highly functional.

Functionality Assessment of Toilet. According to Table 4, besides bathing, the toilet should also facilitate the conduction of traditional washing and storing-1. For storing-1, it would be no big deal as it can be provided on the wall side above, by no particular additional space required. Yet, for washing, space area of 3 sqm should suffice this activity. To be fair, the toilet should be compared with the area of bathroom + washing area that even the maximum existing reached only $63 \%$ achievement, therefore judged as less functional. When the compared space is toilet zone, the capability increased to $84 \%$ by obtaining functional judgment.

Functionality Assessment of Multi-functional Zone. Since ironing is not included in the standardized living-room in the assessment, the standard space for living-room should be added by space for ironing. The result showed not functional for judgment of existing, but highly functional by $115 \%$ for the more public sub-zone and functional by $89 \%$ for the more private subzone. When the standard space is added by the ironing space, the judgment for more public sub-zone of multi-functional zone is no longer highly functional, but just functional, by achieving $95 \%$ capability.

Functionality Assessment of Balcony. Balcony is important in an apartment, as it is the only possible outdoor space in nonindividual dwelling. The activity loads of balcony in this research, listed in Table 4, are drying, storing-1, cooking, dish-washing, and storing-2. Except drying, all the rest of loads are conducted in the other zones i.e. storing- 1 is conducted in the toilet, while the other three activities: cooking, dishwashing and storing-2, take place in the kitchen zone. Users prioritize balcony as the drying place. Yet, it is difficult to find a suitable standard to refer to. Therefore, in this paper the balcony is not assessed as comparable space is not found. 

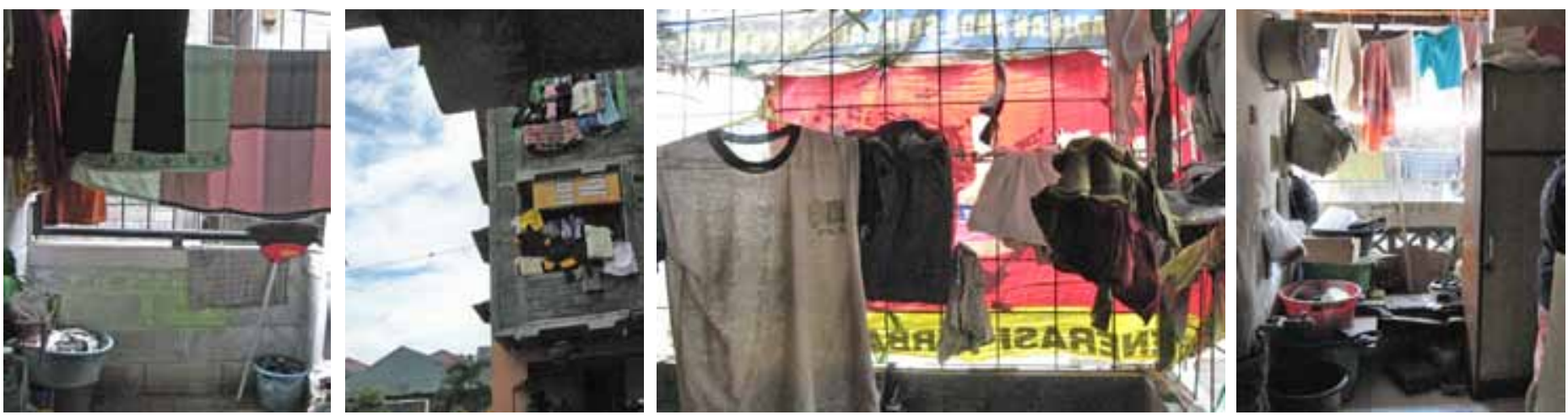

Fig. 6-9. Drying place reality existed at low cost apartments in Surabaya.

\section{CONCLuSions}

When the maximum of whole unit space area of $32 \mathrm{sqm}$ is compared to studio apartment, the judgment can be functional. It means that to be more sustainable, the space area of unit plans in Surabaya deserves to be enlarged to approach the standard in order to prolong the life time. The government has shown increment of unit area in the development of low cost apartments since 1985. In the earliest period of 1990s, unit space area of Sombo, Simo, Dupak, and Penjar-1 was only 18 sqm (Silas, 1990). Toilets and kitchens were provided collectively outside the units. Yet the later built low cost apartments were designed in a larger area, i.e. 21, 24 , and the unit area of Gunungsari as the newest apartment, was $32 \mathrm{sqm}$. Thus, the government has the intention to keep enlarging the unit area to meet standard requirement. Moreover, intension to improve service is also seen, by no longer providing kitchens and toilets collectively, but privately, which, in fact, is more favorable by residents.

For kitchen zone, there is no significant weakness regarding space area provided. For toilet zone, space requirement should share the space for washing, since most respondents do the washing activity traditionally at this zone.

For multi-functional zone, assessment of average and max existing area result in not functional and less functional. Assessment of the zone is divided into public and private subzones. Although the judgment is highly for the former, and functional for the latter, both of them have the consequences. The public sub-zone has 5 active activities that may occur in the same space. 4 of them can take place at the same time, but not ironing. They have to remove all ironing items when suddenly they have guests to entertain. Otherwise they have to share space. In standard, there is no ironing activity in the living-room. Space for ironing is provided separately, which according to Table 1 requires 3 sqm for its own, by which it turns this sub-zone no longer highly functional. As respondents have become accustomed to adapt their activities to the existing space, everything is manageable.

The private sub-zone, which has 4 active activities, has almost the same inclusive activities as those standardized. Both of them prepare spaces for sleeping and relaxing by providing a bed. Yet, beds in this research are mostly just mattresses directly put on the floor instead of on a bed case like that in standard. This bed is not only for sleeping and relaxing, but also for studying and even praying. Most household members require no particular study table including chair for studying, reading or doing homework. As listed in dominant furniture (Table 6), it is seen how high in frequency the use of mattress is. The only difference is that the private sub-zone should provide not only storing-3 that deals with clothes, sheets, and similar, but also storing-2 that deals with food. In fact, bedroom in standard includes only a wardrobe. Multi-functional zone in low cost apartments in Surabaya requires no particular dining space, as residents have storage for food in private sub-zone and eating place in public sub-zone.

For the balcony, it is assumed that the drying space, which is located in the balcony, can be arranged by the determination of its depth influenced by the consideration of how many lines in the drying system are needed, plus some 60 to 90 centimeters for the human movement and circulation.

In conclusion, the space design provided by the government is basically less sufficient but they are acceptable. This acceptance is not purely because of the sufficiency of space provided, but primarily due to the creativity of residents, as well as the adapting capability of users in meeting the space existed to their needs. The simplest example can be presented is related to the functionality of zone spaces, which always are better than that of the existing spaces, and the major use of mattresses is considered to be multifunctional. Residents use mattresses for various activities, not only for sleeping and relaxing, but also for entertaining, eating, TV-watching, ironing, playing, praying, and studying; thus, they can reduce and save the space required. Moreover, when it is possible, they construct mezzanine, extend the balcony, and occupy corridor to extend the space.

Functionality especially the adequacy of space size is really relevant and essential in realizing the sustainability of low cost apartments in Surabaya as this enables residents to live properly and attracts them to stay longer and happier. To improve the functionality, the government has to consider the real daily activities and meet the standard required. The space design seemed not taken into account the users' activities especially the consideration of how and where the users wash, iron, and dry clothes particularly when there is no balcony. The smallest units which areas are $18 \mathrm{~m} 2$ proved inadequacy and inhumane particularly when occupied by more than 4 members, therefore advised to be discontinued. Inhabitants so far by pressure managed to accept the existing space and adapt their space demands to the space provided. Yet, too big space shortage i.e. when occupancy is more than 4, may result in inhumane living, slum impression, and occupation of public space such as the corridor. Accordingly, continuation of largest units which area is $32 \mathrm{~m} 2$ is recommended, even larger if possible, in order to approach the standard. 


\section{REFERENCES}

1. Maslow, A. Motivation and Personality. New York: Harper \& Row, 1970. $268 \mathrm{p}$.

2. Pusat Penelitian dan Pengembangan Permukiman Departemen PU. Standard Arsitektur di bidang Perumahan. Yayasan Lembaga Penyelidikan Masalah Bangunan. Jl. Tamansari 84. Tromolpos 15 Bandung. 1984. p: $24,30-31,46$.

3. Decision-making on mega-projects: cost-benefit analysis, planning and innovation (Edited by Hugo Priemus, Bent Flyvbjerg and Bert van Wee). Cheltenham, UK; Northampton, MA, USA: Edward Elgar Publishing, 2008. P. 30.

4. Rapoport, A. A critical look at the concept "home". The home; words, interpretations, meanings and environments (Editet by D. Benjamin). Brookfield, VT: Ashgate Publishing, 1995. p: 25-52.

5. Silas, J. Rumah Susun Sewa Dupak Bangunrejo Surabaya. Pemda Tingkat II Kotamadya Surabaya collaborated with Housing Laboratory of I.T.S, 1990, p. 16.

6. The state Ministry of Housing Policies on Housing Development (Published by the State Ministry of Housing of Indonesia). Republic of Indonesia, 1994.

7. Breitbart, Mirna Margulies. Quality Housing for Women and Children. Canadian Women Studies / Les Cashier de la Femme, 2007, Vol. 11, No. 2 , p. 19-24.

8. Demirkan, H., Kutlusoy, S. Housing Conditions and Activities of the Middle Income Turkish Household. Journal of Housing Science, 1998, Vol. 22, No. 2, p. 125-136.

9. University of Minnesota, Saint Paul. Designing meaning into the house (Master's thesis by R. Gibbs, 2000).

10. Minami, K. Post Occupancy Evaluation of Layout Changes Made to KEP Adaptable Housing. Journal of Asian Architecture and Building Engineering, 2007, Nov., p. 250.

11. Saarikangas, K. Display of the Everyday, Relations between Gender and the Visibility of Domestic Work in the Modern Finnish Kitchen from the 1930's to 1950's. Journal of Gender, Place and Culture, 2006, April, No. 13, p: 161-172.

12. Szigeti, F., Davis, G. Performance Based Building: Conceptual Framework. PeBBu Final report EUR 21990. Rotterdam, 2005. P. 9. ISBN 90-6363-051-4

13. Apartment Guidelines for mixed use and high density residential developments : Enhancing Our Living Environment. ACT Planning \& Land Authority. 2006.p. 7 [cited 27.07.2012.]. http://apps.actpla.act.gov.au/tplan/ planning_register/register_docs/apartments.pdf

14. West, B.N.,Emmitt, S. Functional Design? An Analysis of New Speculative House Plans in the UK. Design Studies, 2004, No. 25, p. 275-299 [cited 27.07.2012]. http://wenku.baidu.com/view/5c9d9c7301f69e3143329498. html

15. Manning, P. Environmental Evaluation. Building Environment, 1987, Vol. 22, Issue 3, p. 201-108 [cited 27.07.2012]. http://www.sciencedirect. com/science/article/pii/0360132387900084

16. Voordt, T. JM van der, Vrielink, D., Wegen, H. BR van. Comparative Floor Plan Analysis in Programming and Design. Design Studies, 1997, No. 18, p. 67-88 [cited 27.07.2012]. http://www.re-h.tudelft.nl/fileadmin/ Faculteit/BK/Over_de_faculteit/Afdelingen/Real_Estate_and_Housing/ Organisatie/Medewerkers_RE_H/Personal_pages/VanderVoordt/General_ list/doc/1997-DesignStudies_Comparativefloorplananalysis_Voordtetal.pdf

17. Functional / Operational : Last updated 2011 [online]. World Building Design Guide (WBDG) [cited 27.07.2012.]. http://www.wbdg.org/design/ func_oper.php

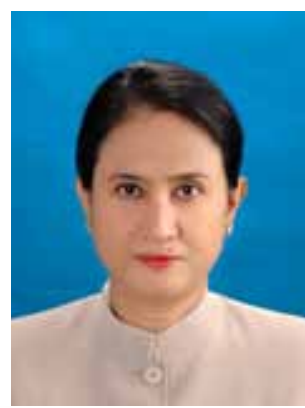

Rika Kisnarini (I.T.S., 1972), B. Arch. (1981), M. uhm (IHS-Erasmus Rotterdam, the Netherlands \& UHM Lund University, Sweden, 2000), on going PhD studies at Unit AUDE Faculty of ABP Eindhoven University of Technology, the Netherlands (research thesis Functionality and Adaptability of Low Cost Apartment Space Design in Tropical Developing Countries; tutor Prof. Jouke M Post).

LECTURER at the Department of Architecture Faculty of Civil Engineering and Planning (I.T.S. since 1983). COORDINATOR of Development Study (Post Graduate Program of I. T. S. since 2004). CHIEF of Architectural Science Laboratory (I. T. S. Department of Architecture, since 2007). MEMBER of Housing laboratory.

- Kisnarini, R. Influence of Geometry on Natural Lighting of Low Cost Flat Common Space. ANZAScA $42^{\text {nd }}$ Annual Conference on Innovation, Inspiration, and Instruction New Knowledge in the Architectural Science, November 26-28, 2008. New Castle (Australia), 2008, p. 327-333.

- Kisnarini, R. Importance of Lifespan Inclusion in Low Cost Apartment Design in Developing Countries. International Symposium on Construction in Developing Economies: Commonalities among Diversities. October 5-7, 2009. Penang (Malaysia), 2009, p. 428-436.

- Kisnarini, R. Maintaining Comfort on Adaptability of Low Cost Apartment Units Due to Changing Demand. $11^{\text {th }}$ Sustainable Environmental Architecture (SENVAR) Conference. October 14, 2010. Surabaya (Indonesia), 2010, p. V1-V8. Current and previous research interests: low cost housing, natural lighting and ventilation. Awards: First Winner of Tanjung Emas Semarang Monument Design 1985. Second runner-up winner of Surabaya Tugu Pahlawan Monument Design Competition 1988.

Membership: member of (East Java) Indonesian Architect Association.

Dr. ir. Emilia van Egmond. MSc in Architecture and Building Engineering, Delft University of Technology, Delft, The Netherlands. PhD in Innovation and Technology Capabilities in Construction, Dept. Civil Engineering, Delft University of Technology.

10 years of practical experience in Architecture and Building Engineering in The Netherlands and abroad, a. o. Ghana, West Africa. More than 25 years academic experience in Innovation and Technology Development for Sustainable Construction in International Perspective.

Member of various international research committees, a. o. CIB on Innovation in Construction; Construction in Developing countries. Further information on the website of Eindhoven University of Technology (TUe) http://www.tue.nl

Dr. ir. Masi Mohammadi. Civil engineering (BSc.), Architectural design and product development (MSc.), and Embedding smart technological innovations in living environment $(\mathrm{PhD}$., Faculty of Architectural Design and Engineering, Eindhoven University of Technology, the Netherlands).

Works as a scientific fellow and lecturer at HAN University of Applied sciences (chair Architecture in Health) and as an Assistant Professor at Eindhoven University of Technology (chair Building Technology), in the Netherlands. Senior researcher and project manager in different nationwide projects based in this field, which help in improving people's quality of life by improving the quality of housing.

Participant of various scientific conferences, an editorial member of the magazine Facility Management Technologies in Healthcare (FMT), and a reviewer of conferences, among them the Gerontechnology World Congress ISG-ISARC 2012.

The focus of the research: Smart and sustainable living environment, New architectural and technological means and methods for enabling aging-in-place and the acceptance of smart (care) applications through domesticating and personalizing it, as well as applying need-based technology in the homes, and the diffusion process of technologies, and empirical studies on the breakthrough of smart care technologies and on the residential needs, and the attitude of users in regards to advanced technological innovations.

\section{Contact Data}

Rika Kisnarini

Department of Architecture, Faculty of Civil Engineering and Planning, I.T.S.

Address: Kampus ITS, Keputih Sukolilo, Surabaya 60111, Indonesia.

Phone: +62 315924301

Email: r.kisnarini@tue.nl or rika@arch.its.ac.id 